THE ARMY OF THE

FRENCH REVOLUTION 



\section{The Army of the \\ French Revolution}

FROM CITIZEN-SOLDIERS

TO INSTRUMENT OF POWER

\section{Jean-Paul Bertaud}

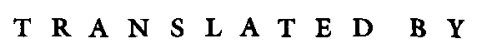

R. R. Palmer 
Copyright (C) 1988 by Princeton University Press Translated from Jean-Paul Bertaud, La Révolution armée

Les soldate-citoyens et la Répolution françatse

Parıs, (C) Editions Robert Laffont, 1979

Published by Princeton University Press, 41 Willam Street, Prunceton, New Jersey 08540

In the United Kingdom

Princeton University Press, Guldford, Surrey

\section{All Rughts Reserved}

This book has been composed in Linotron Galliard Clothbound editions of Princeton University Press books are printed on acid-free paper, and bindıng materials are chosen for strength and durability

Paperbacks, although satısfactory for personal collections, are not usually suitable for library rebindıng

Printed in the United States of America by Princeton Universıty Press, Princeton, New Jersey

Library of Congress Cataloging-ın-Publicatıon Data Bertaud, Jean Paul

The army of the French Revolution

Translation of La révolution armée

Biblıography $\mathrm{p}$ Includes index

I France--History, Mulitary-1789-1815

2 France Armée-History-Revolution, 1789-1799

3 France-History-Revolution, 1789-1799-Influence I Title

DCl51 B4313 $1988 \quad 94404 \quad 88-15098$ ISBN 0-691-05537-8 (alk paper)

Princeton Legacy Library edition 2019

Paperback ISBN: 978-0-691-60474-9

Hardcover ISBN: 978-0-691-65619-9 
I was a child in 1810, when on the Emperor's birthday the draperies hiding the monument at the Place Vendôme were let fall, and the column appeared. I admired it like everyone else. Only I would have liked to know more about the figures in bronze on the bas-reliefs. "And all those men climbing up the column," I said, "what were their names?"

- JULES MICHELET

A great stirring of valorous poverty ... which to save the Revolution expanded it and opened its heart to a larger dream. 
